\title{
Prevalence and Significance of Occult Hepatitis B in a Liver Transplant Population With Chronic Hepatitis C
}

\author{
Kirti Shetty, ${ }^{1}$ Munira Hussain, ${ }^{2}$ Lei Nei, ${ }^{3}$ K. Rajender Reddy, ${ }^{4}$ and Anna S.F. Lok ${ }^{2}$ \\ ${ }^{1}$ Division of Transplantation, Georgetown University Hospital, Washington, DC; ${ }^{2}$ Division of Gastroenterology, \\ University of Michigan Medical Center, Ann Arbor, Ml; ${ }^{3}$ Division of Biostatistics, Georgetown University \\ Hospital, Washington, DC; ${ }^{4}$ Division of Gastroenterology, University of Pennsylvania Medical Center, \\ Philadelphia, PA
}

Occult hepatitis B virus (HBV) infection is defined as the detection of HBV deoxyribonucleic acid (DNA) in the serum or liver tissue of individuals who test negative for hepatitis B surface antigen (HBsAg). We undertook a prospective study to evaluate the significance and course of occult HBV in patients with hepatitis $\mathrm{C}$ virus (HCV) cirrhosis undergoing orthotopic liver transplantation (OLT). A sensitive real-time polymerase chain reaction assay was utilized to test for serum HBV DNA at enrollment and for hepatic HBV DNA within the explant liver. Patients were followed with serum HBsAg and HBV DNA post-OLT. A total of 56 patients with HCV cirrhosis were enrolled between October 2002 and July 2004; of these, 44 underwent OLT. The overall prevalence of occult HBV based on positive serum HBV DNA was 16 of $56(28 \%)$, and based on positive hepatic HBV DNA ("occult HBV liver") was 22 of 44 (50\%). The presence of serum hepatitis B core antibody (anti-HBc) and a past history of injection drug use correlated with occult HBV. Explant-proven hepatocellular carcinoma (HCC) was found in 13 of $22(59 \%)$ patients with occult HBV liver compared to 8 of $22(36 \%)$ patients without occult HBV liver $(P=0.04$, odds ratio $=3.1$; confidence interval $=2.1-5.4)$. Post-OLT, no cases of HBV reactivation were noted, and there was no significant association between occult HBV and recurrent HCV. In conclusion, occult HBV is far more prevalent in patients with end-stage $\mathrm{HCV}$ than would be expected from its prevalence in the general population. Occult HBV infection is strongly associated with the presence of anti-HBc, history of injection drug use, and explant-proven HCC. Liver Transpl 14:534-540, 2008.

(1) 2008 AASLD.

Received December 7, 2006; accepted July 9, 2007.

\section{See Editorial on Page 418}

Sensitive molecular techniques have revealed the persistence of hepatitis B virus (HBV) genomes for decades after recovery from self-limited acute HBV. ${ }^{1}$ This serologically undetectable or "occult" infection is defined as the detection of HBV deoxyribonucleic acid (DNA) in the serum or liver tissue of individuals who test negative for hepatitis B surface antigen (HBsAg). ${ }^{2,3}$ The clinical significance of occult HBV infection is still being defined in terms of its transmissibility, propensity for reactivation, and progression to chronic liver disease. Transmission of HBV from organ and blood donors positive only for the hepatitis B core antibody (anti-HBc) has been shown to result in a de novo hepatitis that is indistinguishable from overt infection. ${ }^{4,5}$ In addition, the development of an immunosuppressed state due to chemotherapy, ${ }^{6}$ organ transplantation, ${ }^{5}$ or human immunodeficiency virus ${ }^{7}$ infection has been shown to induce viral reactivation in patients with occult HBV, with

Abbreviations: HBV, hepatitis B virus; DNA, deoxyribonucleic acid; HBV DNA, hepatitis B viral DNA; HBsAg, hepatitis B surface antigen; HCV, hepatitis C virus; OLT, orthotopic liver transplantation; anti-HBc, hepatitis B core antibody; HCC, hepatocellular carcinoma; RNA, ribonucleic acid; anti-HBs, hepatitis B surface antibody; ACR, acute cellular rejection.

Supported by an American College of Gastroenterology Career Development Award (02/12; 2002-2004 to K.S.).

Address reprint requests to Kirti Shetty, MD, Georgetown University Hospital, 2 Main, 3800 Reservoir Road, Washington, DC 20007. Telephone: 202-444-3700; FAX: 202-444-7304; E-mail: kirti.shetty @ medstar.net

DOI 10.1002/It.21284

Published online in Wiley InterScience (www.interscience.wiley.com). 
appearance of the typical serological profile seen in overt HBV infection.

The significance of occult HBV following orthotopic liver transplantation (OLT) is incompletely understood. An earlier report by Chazouilleres et al. ${ }^{8}$ described the presence of HBV DNA in the serum of $20 \mathrm{HBsAg}$ negative post-OLT patients, attributed to occult pretransplant infection in 5 individuals. Even though the resultant clinical course of affected patients was mild, this study highlighted the concept of reactivation of occult HBV infection. In addition to the direct effects of immunosuppression, the HBV genome has been shown to contain a steroid-responsive DNA sequence that, when stimulated, results in an increase of HBsAg synthesis and HBV gene reactivation. ${ }^{9}$

Cacciola et al. ${ }^{10}$ have offered important insights into the clinical significance of occult HBV in the nontransplant setting. Their analysis demonstrated that $33 \%$ of those with hepatitis $\mathrm{C}$ virus (HCV) infection had evidence of occult HBV infection, compared to $14 \%$ of non-HCV infected controls. Among HCV-infected individuals, those with occult $\mathrm{HBV}$ were more likely to have cirrhosis than those without detectable HBV sequences. These data suggest that occult HBV not only exists at a higher prevalence in those with HCV, but also appears to accelerate its progression.

We therefore undertook this study with 3 specific aims: first, to determine the prevalence of occult HBV in a transplant population with HCV cirrhosis; second, to examine its course post-OLT, i.e., the risk of HBV reactivation in the presence of immunosuppression; and finally, to assess the effect, if any, of occult HBV on the histological recurrence rate of post-OLT HCV.

\section{PATIENTS AND METHODS}

\section{Patient Enrollment}

Patients were prospectively enrolled from the inpatient and outpatient liver transplantation services at the Hospital of the University of Pennsylvania, Philadelphia, PA, USA. The enrollment period was from October 2002 to July 2004. All patients had detectable serum $\mathrm{HCV}$ viral ribonucleic acid (RNA). Each individual had undergone a detailed medical and surgical evaluation and had been placed on the United Network for Organ Sharing waiting list for OLT. Exclusion criteria included the presence of HBsAg, human immunodeficiency virus antibody positivity, use of immunosuppressant medications prior to OLT, prior organ transplant status, acute liver failure, living donor liver transplantation, and use of an anti-HBc positive graft. At the time of enrollment into the study, patients underwent laboratory testing, which included a complete blood count, liver panel, prothrombin time, HBsAg, anti$\mathrm{HBc}$, hepatitis B surface antibody (anti-HBs), HCV antibody, quantitative HCV RNA, and HCV genotype. Serum was collected at enrollment for HBV DNA analysis. At the time of OLT, liver tissue was obtained from the explant, snap-frozen, and HBV DNA analysis was performed. The protocol was approved by the
Institutional Review Board at the University of Pennsylvania.

\section{Patient Follow-Up}

Post-OLT hospital visits occurred as per a standard clinical protocol. At 8 and 24 weeks following OLT, quantitative HCV RNA, HBsAg, and serum HBV DNA analyses were done. Liver biopsies were performed in the presence of abnormal liver-associated enzymes, and were interpreted by 2 experienced hepatopathologists. Recurrent hepatitis $\mathrm{C}$ was defined on the basis of microvascular/macrovascular steatosis, lymphoid aggregates, and bile ductular changes. ${ }^{11}$ The diagnosis of fibrosing cholestatic hepatitis was made based on previously published criteria. ${ }^{12}$ All liver biopsy samples underwent immunohistochemical staining for $\mathrm{HBsAg}$ and hepatitis B core antigen.

The immunosuppression protocol consisted of a steroid taper over 3 months. Tacrolimus was the mainstay of immunosuppression with the goal of target trough levels in the first year between 8 and $12 \mathrm{ng} / \mathrm{mL}$. To minimize tacrolimus exposure, mycophenolate mofetil was used in selected patients with renal insufficiency. In 4 patients transplanted in 2003 and 2004, rapamycin was substituted for tacrolimus, for renal insufficiency presumed to be related to tacrolimus at a median post-OLT follow-up of 7 months.

A total of 12 patients did not undergo OLT, and were not subjected to explant analysis. The true prevalence of occult HBV in these patients could not be accurately assessed. Hence, for the purpose of all comparative analyses, only transplanted patients were included, i.e., 22 patients with positive liver HBV DNA ("occult HBV liver") were compared to 22 patients without evidence of HBV DNA in liver tissue.

None of the patients received oral HBV therapy or prophylaxis after determining the presence of occult HBV.

\section{HCV RNA Analysis}

Serum HCV RNA was detected and genotyped with commercially available assays (COBAS Amplicor HCV; Roche Molecular Diagnostics, Branchburg, NJ and INNO-LIPA HCV II; Innogenetics, Gent, Belgium, respectively). Serum HCV RNA quantification was performed at the time of enrollment and post-OLT using the branched DNA technique, and results were expressed as International Units (IU/mL, Versant 3.0; Bayer Diagnostics, Tarrytown, NY, detection threshold $615 \mathrm{IU} / \mathrm{mL}$ ).

\section{HBV DNA Analysis}

All HBV DNA analyses were done at the University of Michigan laboratories (by M.H. and A.L.).

\section{Quantification of Serum HBV DNA}

HBV DNA was extracted from $200 \mu \mathrm{L}$ of serum using the QIAamp DNA blood minikit (Qiagen,Valencia, CA) and quantified in a real-time polymerase chain reaction 
assay as described previously. ${ }^{13}$ The lower limit of detection of this assay is 25 copies $/ \mathrm{mL}$ and the dynamic range is 1.4 to $10.0 \log _{10}$ copies $/ \mathrm{mL}$.

\section{Quantification of Intrahepatic HBV DNA}

HBV DNA was extracted from $25 \mathrm{mg}$ of liver explants using the QIAamp DNA minikit (Qiagen) and total HBV DNA was quantified in a real-time polymerase chain reaction assay, as described previously. ${ }^{14}$ The lower limit of detection of this assay is $1 \times 10^{-6}$ copies/cell and the dynamic range is -6 to $2 \log _{10}$ copies/cell. To monitor for contamination during each step, sterile double-distilled water and liver specimens from uninfected patients (HBsAg and anti-HBc negative with undetectable HBV DNA in serum by polymerase chain reaction assay) were used as negative controls. Quantification of $\beta$-Actin was used to estimate the amount of genomic DNA in each liver sample.

\section{Statistical Analysis}

Student's t-test and Mann-Whitney test were used to analyze quantitative data. Fisher's exact test was used to analyze qualitative data and for comparing proportions. All $P$ values were 2 -tailed, a $P$ value $<0.05$ was considered to indicate statistical significance. Survival analyses were done utilizing Kaplan-Meier methods.

Multivariate regression analysis was used to assess risk factors for occult HBV liver, as well as for hepatocellular carcinoma (HCC), utilizing age, gender, serological status, alcohol use, and intravenous drug use.

\section{RESULTS \\ Demographics}

A total of 56 patients were enrolled into this study; 3 patients died prior to OLT, and thus only had enrollment serum available for analysis. A total of 9 patients had not undergone OLT at the time of study closure. Of the enrolled patients, 49 (88\%) were male, and $42(75 \%)$ were Caucasian. The mean age at enrollment was 51.9 yr. The mean Model for End-Stage Liver Disease score at enrollment was 17.2 and at OLT was 20.1. The majority of patients (71\%) had HCV genotype 1 infection. Two-thirds (66\%) of the patients had a history of alcohol abuse, $66 \%$ had a past history of intravenous drug abuse.

\section{Prevalence of Occult HBV (Fig. 1)}

\section{Serum Analysis at Enrollment (Pre-OLT)}

A total of 16 of 56 (28\%) patients had detectable serum HBV DNA at enrollment with concentrations varying from 1.7 to $2.3 \log _{10}$ copies $/ \mathrm{mL}$ (median $2 \log _{10}$ copies/ $\mathrm{mL}$ ). Of these patients, 13 underwent OLT, 2 were awaiting OLT at the time of study closure, and the remaining patient died prior to OLT.

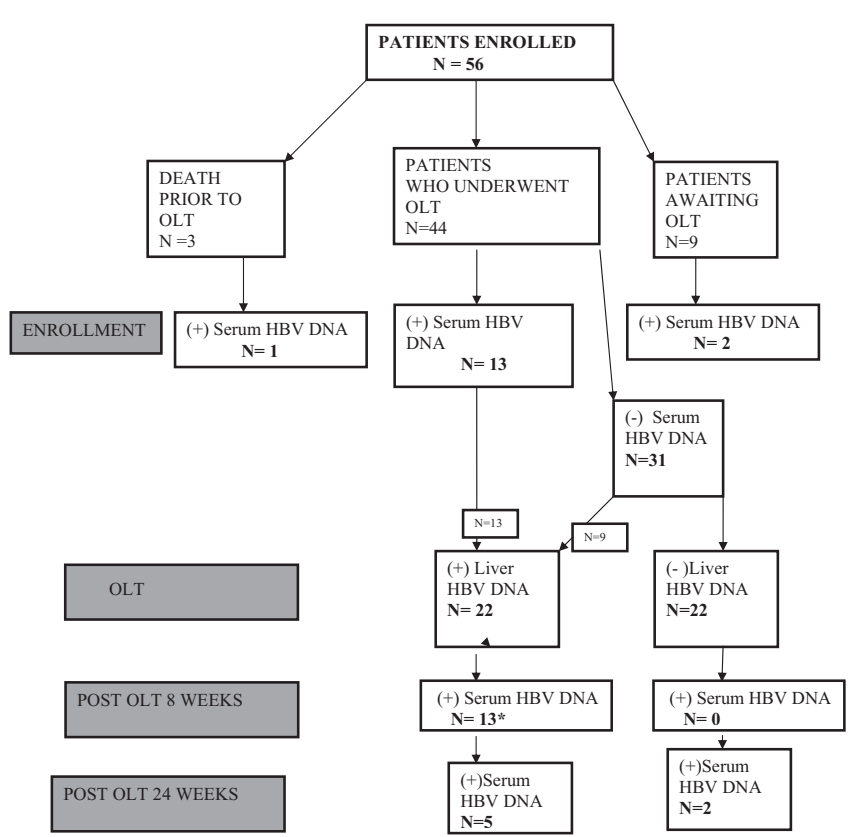

Figure 1. Prevalence of occult HBV-enrollment and follow-up data. *All 13 patients who were serum HBV DNA positive at 8 weeks were explant HBV DNA positive, and all had detectable serum HBV DNA at enrollment.

\section{Explant Liver Analysis}

A total of 22 of 44 (50\%) patients had detectable HBV DNA in their explant liver with concentrations ranging from -0.12 to $-4.9 \log _{10}$ copies/cell (median -2.8 $\log _{10}$ copies/cell). They included all 13 patients with detectable serum HBV DNA at enrollment that underwent OLT and an additional 9 patients who had undetectable serum HBV DNA at enrollment.

Thus, in total, 25 of the 56 patients enrolled (45\%) tested positive for HBV DNA in serum and/or liver.

\section{Risk Factors for Occult HBV Liver (Table 1)}

A total of 22 patients with detectable HBV DNA in the explant liver (designated as having occult HBV liver) were compared to 22 patients without hepatic HBV DNA. On univariate analysis, significant differences were noted between the two groups in terms of MELD score at entry, anti-HBc status, past intravenous drug abuse and explant-proven HCC. No significant differences were noted in terms of age, gender, or racial distribution. On multivariate analysis, anti-HBc status and prior intravenous drug abuse remained significantly associated with occult HBV liver $(P=0.024$ and $P=0.023$, respectively). The Model for End-Stage Liver Disease score at the time of enrollment was significantly higher among those with occult HBV liver (18.6 vs. $16.7, P=0.03$ ).

\section{Association With HCC}

Occult HBV liver was strongly associated with the presence of explant-proven HCC. Of 22 patients with occult HBV liver undergoing OLT, 13 (59\%) had HCC com- 


\begin{tabular}{|c|c|c|c|c|c|}
\hline Variables & $\begin{array}{r}\text { Occult HBV } \\
\text { (liver) }(\mathrm{n}=22)\end{array}$ & $\mathrm{SD}$ & $\begin{array}{r}\text { No occult } \\
\text { HBV(liver) }(\mathrm{n}=22)\end{array}$ & $\mathrm{SD}$ & $P$ value \\
\hline Mean age at enrollment (yr) & 53.1 & 5.2 & 52.8 & 6.2 & NS \\
\hline Mean age at OLT (yr) & 52.7 & 5.4 & 51.9 & 6.3 & NS \\
\hline \multicolumn{6}{|l|}{ Race (\%) } \\
\hline Caucasian & 72.7 & & 72.7 & & \\
\hline AA/Hispanic & 22.8 & & 27.3 & & \\
\hline Asian & 4.5 & & 0 & & \\
\hline MELD at enrollment & 18.6 & 9.5 & 16.7 & 5.8 & 0.03 \\
\hline MELD at OLT & 19.5 & 10.6 & 20.6 & 7.9 & 0.8 \\
\hline IVDA (\%) & 72 & & 56 & & 0.03 \\
\hline Anti-HBc positive (\%) & $12(63)$ & & $6(24)$ & & 0.01 \\
\hline Anti-HBs positive (\%) & $7(36)$ & & $8(32)$ & & 0.6 \\
\hline $\operatorname{ACR}(\%)$ & $6(32)$ & & $2(8)$ & & 0.04 \\
\hline $\mathrm{HCC}(\%)$ & $12(63)$ & & $8(32)$ & & 0.02 \\
\hline Recurrent HCV (\%) & $12(54)$ & & $12(54)$ & & 0.9 \\
\hline
\end{tabular}

Abbreviations: AA, African-American; MELD, Model for End-Stage Liver Disease; IVDA, intravenous drug abuse; ACR, acute cellular rejection; HCC, hepatocellular carcinoma; OLT, orthotopic liver transplantation.

TABLE 2. Hepatitis B Core and Surface Antibody in Relation to Detectable HBV DNA in Serum/Explant Liver

\begin{tabular}{|c|c|c|c|c|c|c|}
\hline & \multicolumn{3}{|r|}{ Anti-HBc +} & \multicolumn{3}{|r|}{ Anti-HBc- } \\
\hline & Total n (\%) & Anti-HBs $+\mathrm{n}$ & Anti-HBs - n & Total n (\%) & Anti-HBs $+\mathrm{n}$ & Anti-HBs - n \\
\hline Enrollment $(\mathrm{n}=56)$ & 27 & & & 29 & & \\
\hline Serum HBV DNA+ $(n=16)$ & $10 / 27(37)$ & 4 & 6 & $6 / 29(21)$ & 1 & 5 \\
\hline Serum HBV DNA- $(n=40)$ & $17 / 27$ (63) & 12 & 5 & $23 / 29$ (79) & 8 & 15 \\
\hline OLT $(\mathrm{n}=44)$ & 18 & & & 26 & & \\
\hline Liver HBV DNA $+(\mathrm{n}=22)$ & $13 / 18(72)$ & 6 & 7 & $9 / 26(35)$ & 1 & 8 \\
\hline Liver HBV DNA- $(\mathrm{n}=22)$ & $5 / 18(28)$ & 2 & 3 & $17 / 26(65)$ & 6 & 11 \\
\hline 8 weeks post-OLT $(\mathrm{n}=44)$ & 18 & & & 26 & & \\
\hline Serum HBV DNA+ $(\mathrm{n}=10)$ & $6 / 18(33)$ & 4 & 2 & $4 / 26(15)$ & 2 & 2 \\
\hline Serum HBV DNA- $(\mathrm{n}=34)$ & $12 / 18(67)$ & 5 & 7 & $22 / 26(85)$ & 4 & 18 \\
\hline 24 weeks post-OLT $(\mathrm{n}=42)$ & 16 & & & 26 & & \\
\hline Serum HBV DNA+ $(\mathrm{n}=7)$ & $3 / 16$ (19) & 1 & 2 & $4 / 26(15)$ & 1 & 3 \\
\hline Serum HBV DNA- $(\mathrm{n}=35)$ & $13 / 16(81)$ & 6 & 7 & $22 / 26(85)$ & 4 & 18 \\
\hline
\end{tabular}

pared to 8 of $22(36 \%)$ without occult HBV liver $(P=$ 0.04 ; odds ratio $=3.1$; confidence interval $=2.1-5.4$ ). On multivariate analysis incorporating age, alcohol abuse, and gender, only occult HBV remained significant $(P=0.05)$. Hepatic HBV DNA concentrations were comparable in those with and without HCC (median: 2.78 vs. $-2.82 \log _{10}$ copies/cell; $P=0.08$ )

\section{Post-OLT Follow-Up}

A total of 44 patients who survived more than 3 months post-OLT were further analyzed to delineate the postOLT course of occult HBV. The median post-OLT follow-up was 13.2 months (range 3-25 months).

\section{Post-OLT Course of Occult HBV Liver}

Of the 22 patients who had HBV DNA detectable in the explanted liver, 13 had detectable serum HBV DNA at 8 weeks post-OLT (range 1.7-2.6 $\log _{10}$ copies/mL, median $2.1 \log _{10}$ copies / $\mathrm{mL}$ ), all of whom had detectable serum HBV DNA pre-OLT. A total of 7 patients had HBV detectable at 24 weeks post-OLT (range 2.2-3.3 $\log _{10}$ copies/mL, median $2.2 \log _{10}$ copies $/ \mathrm{mL}$ ). Interestingly, 2 patients who had detectable serum HBV DNA at 24 weeks post-OLT did not have detectable HBV DNA in the explant liver, and had undetectable serum HBV DNA at week 8 post-OLT. Their serological correlates are illustrated in Table 2.

No detectable HBsAg was noted at 8 or 24 weeks in any of the patients tested, and all patients tested negative for HBsAg by immunostains on post-OLT liver biopsy specimens $(n=46)$. A total of $6(32 \%)$ of those with occult HBV liver suffered at least 1 episode of acute cellular rejection (ACR), compared to 2 patients $(8 \%)$ without explant HBV DNA $(P=0.04)$. All rejection episodes with a rejection activity index $\geq 6$ were treated with a modified steroid regimen $(n=4)$. Refractory rejection episodes requiring the use of thymoglobulin or monoclonal antibodies were not noted.

Of the 22 patients with occult HBV liver, 1 of 13 with 
and 1 of 9 patients without detectable serum HBV DNA at week 8 received a steroid pulse for ACR. Among the 22 patients without occult HBV liver, 1 of 2 patients who manifested serum HBV DNA at 24 weeks and 1 patient who had undetectable serum HBV DNA at week 8 and 24 received a steroid pulse for ACR. No association could be noted between post-OLT appearance of serum HBV DNA and immunosuppressant regimen/ steroid pulses.

\section{Serological Correlates}

The presence of occult HBV correlated highly with the anti-HBc status. Of 16 patients with detectable serum HBV DNA at enrollment, $10(63 \%)$ were positive for anti-HBc, whereas only 17 (42\%) out of the 40 patients without serum HBV DNA tested positive for anti-HBc $(P=0.04)$. There was no significant difference in HBV DNA concentrations in those with and without antiHBc (mean 1.8 [standard deviation 0.3] $\log _{10}$ cop$\mathrm{ies} / \mathrm{mL}$ vs. 1.9 [standard deviation 0.3 ] $\log _{10}$ copies/ $\mathrm{mL}$, respectively; $P$ value not significant). Similarly, of the 22 patients who had detectable hepatic HBV DNA, 13 (59\%) were positive for anti-HBc ( 7 were negative for anti-HBs) compared to 4 of 22 patients (18\%) with undetectable explant HBV DNA $(P=0.03)$. Again, no difference in hepatic HBV DNA concentration was noted in those who were anti-HBc positive vs. those who were anti-HBc negative $\left(-2.55\right.$ and $-2.78 \log _{10}$ copies/cell, respectively; $P$ value not significant). Interestingly, 7 patients with detectable explant HBV DNA were negative for all markers of prior HBV infection.

Conversely, 37\% of those who were anti-HBc positive had detectable serum HBV DNA at enrollment, compared to $21 \%$ of those who were anti-HBc negative $(P=$ 0.05). Similarly, $72 \%$ of anti-HBc positive patients had detectable hepatic HBV DNA, compared to $35 \%$ of those who were anti-HBc negative. This detailed serological data is illustrated in Table 1.

\section{Recurrence Rates of HCV}

Liver biopsies were not performed on a protocol basis but were prompted by abnormal liver-associated enzymes. With this approach, an overall histological recurrence rate of $54 \%$ was noted. The median time interval between OLT and the first documented recurrence was 7.3 months (2.2 to 14.1 months). The recurrence rate was 12 of $22(54 \%)$ in patients with and 12 of $22(54 \%)$ in those without occult HBV liver $(P=$ not significant). There were no significant differences in the duration of follow-up and the mean number of liver biopsies performed between the 2 groups. By multivariate regression analysis, recurrent $\mathrm{HCV}$ was associated with HCV viral load (pre-OLT RNA >850,000 IU/L), $\mathrm{ACR}$, and donor age $>60 \mathrm{yr}$. It did not correlate with the presence of occult HBV liver. This data is summarized in Table 1.

\section{Post-OLT Outcomes}

A total of 5 patients died during their follow-up at a median of 13.25 months from transplantation. A total of 2 deaths occurred in patients with no evidence of occult HBV liver-both attributed to overwhelming sepsis at 92 days and 13 months, respectively, post-OLT. A total of 3 deaths occurred in patients with occult HBV liver; 1 from fibrosing cholestatic hepatitis $\mathrm{C}$ occurring 20 months post-OLT and 6 months following treatment of biopsy-proven ACR, 1 due to recurrent HCC 16 months from OLT, and 1 due to sepsis at 22 weeks post-OLT. An additional patient with occult HBV liver suffered recurrent fibrosing cholestatic hepatitis $\mathrm{C}$ and was retransplanted at 8 months from the time of initial OLT, and 7 months following initial documentation of histological recurrence. Using Kaplan-Meier survival analyses, no difference in survival was noted. One-year patient survival rates were $94.8 \%$ in the occult HBV liver group vs. 95\% in the non-occult HBV liver group $(P=$ not significant $)$.

\section{DISCUSSION}

The prevalence of occult HBV has been reported to vary depending on the exposure of the overall population to $\mathrm{HBV}$, as well as the severity of liver disease, being higher in patients with cirrhosis and HCC. As such, its prevalence differs widely - a study from Japan demonstrated a $75 \%$ prevalence in HCV-infected patients with significant liver disease ${ }^{15}$ while a similarly conducted study from France showed a 5.5\% prevalence. ${ }^{16}$ In the United States, occult HBV infection is reported in 0 to $9 \%$ of the blood donor population, as compared to 7 to $19 \%$ in endemic areas. ${ }^{17,18}$ There is a paucity of North American data examining occult HBV in patients with chronic liver disease. A Canadian study demonstrated its prevalence in 7 of 36 or $19.5 \%$ of those with undefined chronic liver disease. ${ }^{19}$ Another study of a Canadian hemodialysis population found that $3.8 \%$ of 239 HBsAg-negative patients were HBV DNA positive. Viral loads in these individuals were low $\left(10^{2}-10^{4}\right.$ viral copies $/ \mathrm{mL}$ ), and $78 \%$ of those tested had a mutation in the HBV surface gene (sG145R mutant) that may lead to false-positive results in some serologic assays for HBsAg. Demographic, biochemical, and HBV serological testing did not help to identify those with occult HBV. ${ }^{20}$

Our study is the first to systematically examine the prevalence rate and course of occult HBV in a U.S. population with end-stage HCV undergoing OLT, utilizing a highly sensitive real-time polymerase chain reaction assay. The $50 \%$ prevalence rate of occult HBV on explant liver analysis is far higher than would be expected in an area of low endemicity, but may be explained by the fact that common risk factors predispose to the acquisition of both viruses. Upon analysis of these factors, intravenous drug abuse and positive anti-HBc correlated with occult HBV. It should be noted that all patients had very low concentrations of HBV DNA. We found no evidence of overt HBV reactivation as defined by appearance of serum HBsAg, an observation 
in keeping with a recent Italian study that examined the significance of occult HBV in the post-OLT setting, as well as an earlier retrospective analysis of stored sera. $^{21,22}$

One novel finding in our study was the appearance of serum HBV DNA post-OLT. This occurred not only in those with demonstrable HBV DNA in their explant liver, but also in 2 patients without explant HBV DNA. No definite correlation could be observed between steroid pulses for ACR and this phenomenon of viral emergence. There was no linear correlation noted between pre-OLT serum HBV DNA or explant HBV DNA levels with post-OLT serum HBV DNA. However, our results may be limited by the relatively small numbers of patients in each group.

Occult HBV is often reported in the context of other HBV serologies. Of the 22 patients with positive liver HBV DNA described in our study, the majority (59\%) were anti-HBc positive, most of whom were negative for anti-HBs. This is in keeping with earlier studies that report the highest prevalence of occult $\mathrm{HBV}$ in anti-HBc positive, anti-HBs negative individuals. ${ }^{2}$ Interestingly, 7 occult HBV liver patients (23\%) had no markers of prior HBV infection, a phenomenon that has also been described. ${ }^{2}$ Plausible explanations for this phenomenon involve mutations in the $\mathrm{S}$ gene, leading to falsenegative HBsAg test result, or in the preS region, and downregulation of HBsAg expression. ${ }^{23}$

The molecular basis of HBV persistence in HBsAg negative subjects is believed to involve a combination of viral and host-dependent factors. One of the main characteristics of these infections is the very low level of circulating viral DNA and the low copy number per cell of viral genomes in liver samples. ${ }^{22}$ This is confirmed in our study, in which serum HBV DNA $>3 \log _{10}$ copies/mL pre- and post-OLT and explant liver HBV DNA $>-1.0 \log _{10}$ copy/cell was observed in 0,1 , and 2 patients, respectively. Host-related factors are important in immune clearance of HBV. Ample evidence now exists that cytokines such as tumor necrosis factor $\alpha$ and interferon $\gamma$ play a major role in the posttranscriptional downregulation and intracellular inactivation of HBV genome expression. Synthesis of these cytokines depends on HBV-specific cytotoxic T lymphocytes. ${ }^{24-26}$ In the post-OLT setting, the use of steroids and immunosuppressants modifies the activity of these T-lymphocytes, and would theoretically cause reactivation of the latent virus. However, the absence of de novo HBV infection in our post-OLT population suggests that the removal of the major reservoir of HBV (i.e., the host liver) essentially eliminates the possibility of reactivation noted in the setting of other organ transplants.

In our study, the prevalence of occult HBV among those with HCC was significantly higher than in those without HCC. This data is consistent with epidemiological and molecular studies, which implicate a possible oncogenic role for occult $\mathrm{HBV}$ in the development of HCC. ${ }^{27-30}$ The mechanisms whereby occult HBV infection contributes to hepatocellular transformation are likely similar to that of overt HBV infection. ${ }^{28}$

In our study, histological HCV recurrence occurred at a rate of approximately 50\%, comparable to other studies. ${ }^{31}$ On multivariate analysis, $\mathrm{HCV}$ recurrence was associated with at least 1 episode of ACR, pre-OLT viral load $>850,000$ and donor age $>60 \mathrm{yr}$. Occult HBV infection was not a risk factor for recurrent $\mathrm{HCV}$. This is consistent with a retrospective analyses of stored sera reported recently. ${ }^{32}$ It should be noted that protocol liver biopsies were not performed at our center, but were prompted by abnormal liver biochemistry. Therefore, the possibility exists of having underestimated $\mathrm{HCV}$ recurrence. Additionally, histological HCV recurrence may not have been an appropriate end-pointperhaps progression or severity of recurrence would have been a more useful indicator of outcome. Only a small number of our patients had serial liver biopsies, making analysis of histological progression difficult.

In summary, our prospective analysis found a high prevalence of occult HBV in a U.S. transplant population with end-stage HCV. All patients had low circulating and intrahepatic HBV DNA concentrations. The presence of occult $\mathrm{HBV}$ is most reliably predicted by positive anti-HBc/negative anti-HBs status of the subject. A strong association was noted between the presence of occult HBV and the development of HCC. De novo cases of hepatitis $B$, defined as appearance of serum HBsAg, were not detected. Although post-OLT serum HBV DNA was transiently detected in some patients, at the present time anti-HBV therapy cannot be recommended for this population. Larger studies will be required to determine the true effect of occult $\mathrm{HBV}$ on HCV recurrence post-OLT.

\section{REFERENCES}

1. Penna A, Artini M, Cavalli A, Levrero M, Bertoletti A, Pilli $\mathrm{M}$, et al. Long-lasting memory $\mathrm{T}$ cell responses following self-limited acute hepatitis B. J Clin Invest 1996;98:11851194.

2. Brechot C, Thiers V, Kremsdorf D, Nalpas B, Pol S, Paterlini-Brechot P. Persistent hepatitis B virus infection in subjects without hepatitis B surface antigen : clinically significant or purely "occult”? Hepatology 2001;34:194203.

3. Conjeevaram HS, Lok AS. Occult hepatitis B virus infection: a hidden menace? Hepatology 2001;34:204-206.

4. Hoofnagle JH, Seefe LB, Bales ZB, Zimmerman HJ. Type B hepatitis after transfusion with blood containing antibody to hepatitis B core antigen. N Engl J Med 1978;298:13791383.

5. Dickson RC, Everhart JE, Lake JR, Wei Y, Seaberg EC, Wiesner RH, et al. Transmission of hepatitis B by transplantation of livers from donors positive for antibody to hepatitis B core antigen. The National Institute of Diabetes and Digestive and Kidney Disease Liver Transplantation Database. Gastroenterology 1997;113:1668-1674.

6. Imamura $\mathrm{T}$, Yokosuka $\mathrm{O}$, Chiba $\mathrm{T}$, Kanda $\mathrm{T}$, Kojima $\mathrm{H}$, Fukai $\mathrm{K}$, et al. Lamivudine treatment in a patient with hepatitis B virus reactivation after allogenic peripheral bone marrow transplantation. Leuk Lymphoma 2005;46; 915-917.

7. Puoti M, Torti C, Bruno R, Filice G, Carosi G. Natural history of chronic hepatitis B in co-infected patients. J Hepatol 2006;44(Suppl 1):S65-S70.

8. Chazouilleres O, Mamish D, Kim M, Carey K, Ferrell L, Roberts JP, et al. "Occult" hepatitis B virus as source of 
infection in liver transplant recipients. Lancet 1994;343: 142-146.

9. Angus PW. Hepatitis B and liver transplantation. J Gastroenterol Hepatol 1997;12:217-223.

10. Cacciola I, Pollicino T, Squadrito G, Cerenza G, Orlando M, Raimondo G. Occult hepatitis B virus infection in patients with chronic hepatitis C liver disease. N Engl J Med 1999;341:22-26.

11. Sreekumar R, Gonzalez-Koch A, Maor-Kendler Y, Batts K, Moreno-Luna L, Poterucha J, et al. Early identification of recipients with progressive histologic recurrence of hepatitis C after transplantation. Hepatology 2000;32:11251130.

12. Schluger LK, Sheiner PA, Thung SN, Lau JY, Min A, Wolf DC, et al. Severe recurrent cholestatic hepatitis C following orthotopic liver transplantation. Hepatology 1996;23: 971-976.

13. Liu Y, Hussain M, Wong S, Fung SK, Yim HJ, Lok ASF. A genotype-independent real-time PCR assay for quantification of hepatitis B virus DNA. J Clin Microbiol 2007;45: 553-558.

14. Hussain M, Soldevila-Pico C, Emre S, Luketic V, Lok AS, the NIH HBV-OLT Study Group. Presence of intrahepatic (total and ccc) HBV DNA is not predictive of HBV recurrence after liver transplantation. Liver Transpl 2007;13: 1137-1144.

15. Tamori A, Nishiguchi S, Kubo S, Koh N, Moriyama Y, Fujimoto S, et al. Possible contribution to hepatocarcinogenesis of X transcript of hepatitis B virus in Japanese patients with hepatitis C virus. Hepatology 1999;29:14291434.

16. Porchon C, Kremsdorf D, Pol S, Lunel-Fabianni F, Driss F, Opolon $\mathrm{P}$, et al. Serum hepatitis $\mathrm{C}$ virus RNA and hepatitis $B$ virus DNA in non-A, non-B post-transfusional and sporadic chronic hepatitis. J Hepatol 1992;16:184-189.

17. Douglas DD, Taswell H, Rakela J, Rabe D. Absence of hepatitis B virus DNA detected by polymerase chain reaction in blood donors who are hepatitis B surface antigen negative and antibody to hepatitis $\mathrm{B}$ core antigen positive from a United States population with a low prevalence of hepatitis B serologic markers. Transfusion 1993;33:212216.

18. Iizuka H, Ohmura K, Ishijima A, Satoh K, Tanaka T, Tsuda $\mathrm{F}$, et al. Correlation between anti-HBc titers and HBV DNA in blood units without detectable HBsAg. Vox Sang 1992; 63:107-111.

19. Scully LJ, Sung H, Pennie R, Gill P. Detection of hepatitis $B$ virus DNA in the serum of Canadian hepatitis B surface antigen negative, anti-HBc positive individuals, using the polymerase chain reaction. J Med Virol 1994;44:293-297.

20. Minuk GY, Sun DF, Greenberg R, Zhang M, Hawkins K,
Uhanova $\mathrm{J}$, et al. Occult hepatitis B virus infection in a North American adult hemodialysis patient population. Hepatology 2004;40:1072-1077.

21. Ghisetti V, Marzano A, Zamboni F, Barbui A, Franchello A, Gaia S, et al. Occult hepatitis B virus infection in HBsAg negative patients undergoing liver transplantation: clinical significance. Liver Transpl 2004;10:356-362.

22. Abdelmalak MF, Pasha TM, Zein NN, Persing DH, Wiesner RH, Douglas DD. Subclinical reactivation of hepatitis B virus in liver transplant recipients with past exposure. Liver Transpl 2003;9:1253-1257.

23. Chaudhuri V, Tayal R, Nayak B, Acharya SK, Panda SK. Occult hepatitis B virus infection in chronic liver disease: full-length genome and analysis of mutant surface promoters. Gastroenterology 2004;127:1356-1371.

24. Sagnelli E, Coppola N, Scolastico C, Filippini P, Santantonio T, Stroffolini T, Piccinino F. Virologic and clinical expressions of reciprocal inhibitory effect of hepatitis B, C, and delta viruses in patients with chronic hepatitis. Hepatology 2000;32:1106-1110.

25. Guidotti LG, Rochford R, Chung J, Shapiro M, Purcell R, Chisari FV. Viral clearance without destruction of infected cells during acute HBV infection. Science 1999;284:825829.

26. Szkaradkiewicz A, Jopek A, Wysocki J. Effects of IL-12 and IL-18 on HBcAg-specific cytokine production by CD4 T lymphocytes of children with chronic hepatitis B infection. Antiviral Res 2005;66:23-27.

27. Huo TI, Wu JC, Lee PC, Chau GY, Lui WY, Tsay SH, et al. Seroclearance of hepatitis B surface antigen in chronic carriers does not necessarily imply a good prognosis. Hepatology 1998;28:231-236.

28. Marrero JA, Lok ASF. Occult hepatitis B infection in patients with hepatocellular carcinoma: innocent bystander, cofactor or culprit? Gastroenterology 2004;126:347-350.

29. Pollicino T, Squadrito G, Cerenzia G, Cacciola I, Raffa G, Craxi A, et al. Hepatitis B virus maintains its pro-oncogenic properties in the case of occult HBV infection. Gastroenterology 2004;126:102-110.

30. Ikeda K, Marusawa H, Osaki Y, Nakamura T, Kitajima N, Yamashita Y, et al. Antibody to hepatitis B core antigen and risk of hepatitis C-related hepatocellular carcinoma: a prospective study. Ann Intern Med 2007;146:649-656.

31. Park YN, Boros P, Zhang DY, Sheiner P, Kim-Schluger L, Thung SN. Serum hepatitis C virus RNA levels and histologic findings in liver allografts with early recurrent hepatitis C. Arch Pathol Lab Med 2000;124:1623-1627.

32. Hui C-K, Lau E, Monto A, Kim M, Luk JM, Poon, RTP, et al. Natural history of patients with recurrent chronic hepatitis $\mathrm{C}$ virus and occult hepatitis B co-infection after liver transplantation. Am J Transplant 2006;6:1600-1608. 